Article Type: Research Paper

\title{
The Effect of Marketing Mix on Purchase Decisions
}

\author{
Ani Nor Widyastuti ${ }^{1 *}$, Pujiharto $^{1}$, Naelati Tubastuvi ${ }^{1}$,
} and Suryo Budi Santoso ${ }^{1}$

\begin{abstract}
This research is essential to contribute to the minimarket with campus brands, which live and thrive in the campus environment to better understand the marketing mix factors that influence purchasing decisions. The campus is expected to provide a special image for consumers. This research discusses the marketing mix factors on consumer purchasing decisions in minimarkets with campus brands in the Banyumas Regency, namely Boersa Kampus (Unsoed), Top Campus (Unsoed, UMP), Kopkun Swalayan (Unsoed), Indo Kampus (STAIN), and UeMPe Mart (UMP). The factors used were the product, price, promotion, service, and place/location. The sample used amounted to 100 respondents who were consumers with more than 17 years of age. The sampling employed nonprobability with a purposive sampling technique, and data analysis utilized multiple linear regression. The adjusted R-square value indicates that the dependent variable was influenced by the independent variable by $54.3 \%$. The results showed that the product, price, promotion, service, and place/location variables simultaneously determined purchase decision. Partially, product and place/location variables determined positively and significantly towards purchasing decisions, while price, promotion, and service variables did not affect purchase decisions. Future research can be carried out using the campus brand as a mediating variable.
\end{abstract}

Widyastuti, A. N., Pujiharto, Tubastuvi, N., \& Santoso, S. B. (2020). The Effect of Marketing Mix on Purchase Decisions (Study on Minimarket Consumers with Campus Brands in the Banyumas Regency). Jurnal Manajemen Bisnis, 11(2), 163-176.

\section{ARTICLE HISTORY}

Received:

16 January 2020

Reviewed:

03 April 2020

02 July 2020

Revised:

08 May 2020

03 July 2020

Accepted:

04 July 2020

\section{Introduction}

The retail business in Indonesia is overgrowing in various forms, especially in the form of a minimarket. The rapid development of the minimarket is driven by the expansion of the network minimarket business that controls around $87 \%$ of the market share, and it can become a minimarket business opportunity for local entrepreneurs. The use of the term minimarket in this study refers to stores that sell basic foodstuffs and daily necessities (https://www.aprindo.id, 2018).

The value of modern retail sales in 2016, 2017, and 2018 reached Rp 205 trillion, Rp 212 trillion, and Rp 233 trillion, respectively. Although slowing down for three consecutive years, retail continued to grow. Minimarket is one type of retail business that is still very prospective. It relates to changes in modern lifestyles that encourage consumers to prefer to shop 
for retail needs in the nearest place (Richard, 2019). Indonesia was in 15th position among developing countries as a destination for retail investment, as reported by the Global Retail Development Index (GRDI). Despite various challenges, especially related to increasingly stringent government regulations, Indonesia remains a promising retail market and provides large retail investment opportunities in the medium to long term (Kearney (2014) in (Syahmardi, 2017).

The retail business in the Banyumas Regency is growing rapidly, with more players making business competition getting tougher. Among the retail business players, a minimarket grows in the campus environment of several universities. Minimarkets in the campus environment, which are developed with the campus brand by public entrepreneurs and the civitas academics, can be places for the civitas academics, especially students, to learn indirectly about the minimarket business that knowledge transfer takes place. The minimarket in this study is a local minimarket, not a network, so the role that has been controlled by network retailers, such as Alfamart and Indomaret, is possible to be distributed to many parties. It is because more and more people understand and are interested in running the retail business.

Campus brands are expected to provide a special image for customers, namely that "regardless of the ability to pay, all shoppers seek stores whose total image is acceptable and appealing to them individually" (Mokhlis, 1999); (Verma \& Madan, 2011). It can be interpreted that regardless of the ability to pay, all consumers look for stores with an acceptable and attractive total image to them individually. Consumers will shop at the minimarket that imaged themselves; in this case, especially the civitas academics will feel more comfortable shopping at their shop. The people in the campus environment are comfortable shopping at the minimarket with the campus brand because they feel they are part of the campus environment. This research is vital to contribute to the minimarket with campus brands, which live and thrive in the campus environment to better understand the marketing mix factors that influence purchasing decisions associated with campus brands.

Furthermore, this research will provide a reference for minimarkets with campus brands in determining the right marketing strategy. The marketing strategy is absolutely necessary to deal with the high level of competition between minimarkets, even with traditional shops that are pretty much around the campus. By better understanding the desires of the target market, consumers can be diverted to choose a minimarket with a campus brand, not a competitor minimarket.

Thus, there are several research questions, as follows:

1. Does the product have a positive and significant effect on purchasing decisions at the minimarkets with campus brands in the Banyumas Regency?

2. Does the price have a positive and significant effect on purchasing decisions on minimarkets with campus brands in the Banyumas Regency?

3. Does the promotion have a positive and significant effect on purchasing decisions at the minimarket with campus brands in the Banyumas Regency? 
4. Does the service have a positive and significant effect on purchasing decisions on minimarkets with campus brands in the Banyumas Regency?

5. Does the place/location have a positive and significant effect on purchasing decisions at the minimarkets with campus brands in the Banyumas Regency?

The objectives of this study are as follows:

1. To analyze the effect of the product on purchasing decisions on minimarkets with campus brands in the Banyumas Regency.

2. To analyze the effect of prices on purchasing decisions on minimarkets with campus brands in the Banyumas Regency.

3. To analyze the effect of promotion on purchasing decisions on minimarkets with campus brands in the Banyumas Regency.

4. To analyze the effect of service on purchasing decisions on minimarkets with campus brands in the Banyumas Regency.

5. To analyze the effect of place/location on purchasing decisions on minimarkets with campus brands in the Banyumas Regency.

\section{Literature Review and Hypotheses Development}

Minimarkets in the campus environment that are developed with the campus brand by public entrepreneurs and the civitas academics can be places for the civitas academics, especially students, to learn indirectly about the minimarket business, so that knowledge transfer takes place. With this development, it is expected that the role that has been controlled by network retailers, such as Alfamart and Indomaret, is possible to be distributed to many parties because more and more people understand and are interested in running the retail business.

In general, consumers look for stores whose total image is acceptable and appealing to them individually. Consumers will shop at the minimarket that imaged themselves; in this case, especially the civitas academics will feel more comfortable shopping at their shop. The people in the campus environment are comfortable shopping at the minimarket with the campus brand because they feel they are part of the campus environment.

The purchasing decision is the consumer's process in determining to purchase a product or service among several available alternatives (Kotler \& Keller, 2009). In the process of determining their decisions, consumers are influenced by one of which is marketing stimuli. Marketing stimuli related to the marketing mix consist of product strategy, price strategy, distribution (place) strategy, and promotion strategy.

The modern Marketing Mix 4Ps theory was first put forward by E. Jerome McCarthy and subsequently popularized by Phillip Kotler (https://en.wikipedia.org/wiki/Marketing_mix, n.d.). A marketing mix is a marketing tool that is used on an ongoing basis by companies to achieve marketing objectives (Kotler, 2007). If the target market has been determined through marketing research, it must make a good plan to enter the chosen market 
segment. The marketing mix that is applied must be able to integrate product strength, price advantage, distribution channels, and promotional strategies in winning a competition (Kartajaya, 2007).

As minimarket network that has been developed before, minimarket with campus brand also has the quality and diverse products, with affordable prices, attractive and broad promotions, good service, and strategic places/locations so that they can compete to attract potential customers who will make a purchase, both from students and the surrounding community.

\section{Product}

Product is a combination of goods and services offered by the company to the target market (Kotler, 2007); it is something, which can be offered to the market to be bought, used, or consumed that can satisfy the desires or needs of consumers (Kotler \& Armstrong, 2007). Products can meet the desires and needs of consumers. In addition to the physical form of the product, it also includes services. Product quality and product diversity are key elements in competition between retail businesses.

\section{Price}

Price is the amount of money that consumers exchange for benefits in using a product or service. Price is the key determinant of buyer choice. Price is the only element of the marketing mix generating income, while other elements cause financing (Kotler, 2007). The price of a product, in this case, is in accordance with the quality of the product offered. Low prices are usually a valuable source of satisfaction for price-sensitive customers because customers will get high value for money. Pricing is very decisive in giving value to consumers and affects the image of the product, which ultimately gives an influence on purchasing decisions.

\section{Promotion}

Promotion means an activity that conveys the benefits of the product and is persuading consumers to buy the product offered (Kotler, 2007). It includes all activities undertaken by the company to consume the benefits of its products and convince consumers to be willing to take action to buy. Sales promotion aims to maintain consumer interest in continuing to shop at the retail, introduce new products/outlets, compete with competitor programs, lure potential customers, and take advantage of trends in consumer shopping behavior patterns (Utami, 2010). Sales promotion is a form of direct persuasion through the use of various incentives that can be arranged to stimulate the purchase of products immediately and or increase the number of items purchased by consumers (Hermawan, 2012). 


\section{Service}

Services are actions that can be offered to other parties, mostly intangible, and do not produce any ownership (Kotler \& Keller, 2009). Thus, the service provided by a minimarket is an effort made to provide satisfaction to its consumers. Service quality is an essential factor for a minimarket to survive and gain consumer trust. The quality of this service is evaluated by looking at five characteristics as follows a) Responsiveness: response/alertness of employees in helping consumers and providing services that are quick to respond, b) Reliability: the ability to deliver the promised service accurately and reliably, c) Assurance: the ability of employees for proper product knowledge, quality, hospitality, speech, or politeness in providing services, skills in providing information, and the ability to instill consumer trust in the company, d) Empathy: the company's ability to provide personal attention to consumers, e) Tangibles: forms of physical appearance, personal equipment, communication media, and other physical things.

\section{Place/Location}

Places include company activities that make products available to customers (Kotler, 2007). The place is a location where minimarkets operate or carry out activities to produce goods or services that enhance their economic aspects (Alma, 2007). Location is seen as a place of business that greatly affects consumers' desire to come and shop (Sumarwan, 2004).

\section{Conceptual Framework}

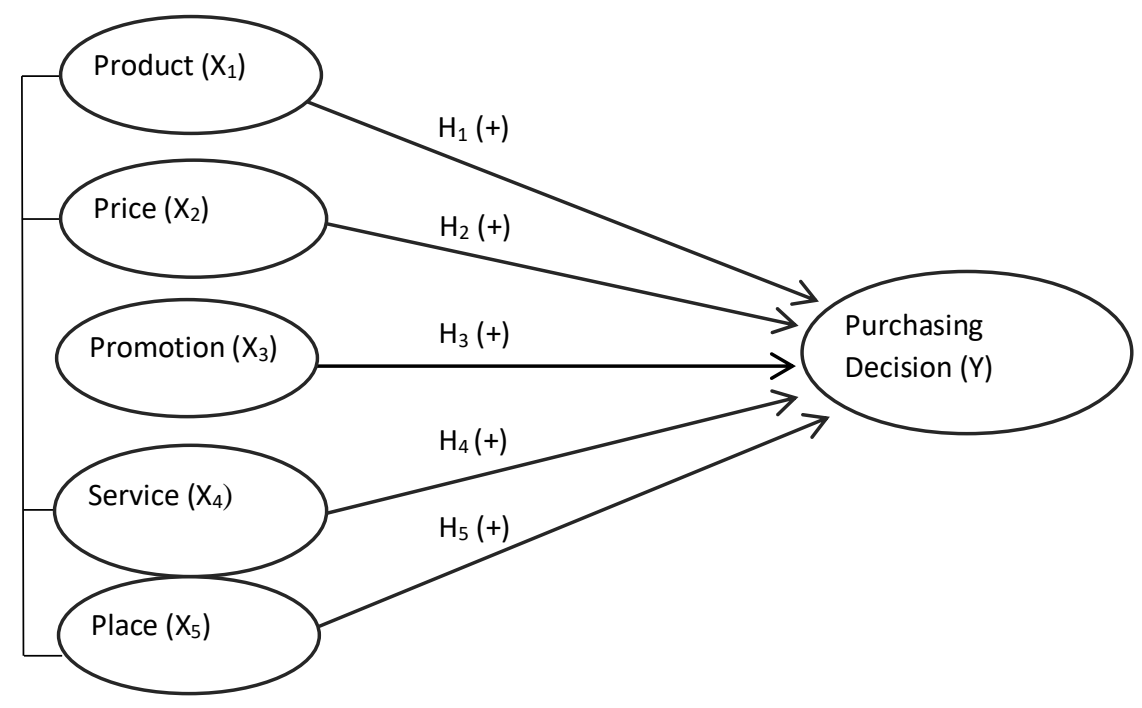

Figure 1 Research Model

Source: Kotler \& Keller (2009), processed by researchers 


\section{Research Hypothesis}

In connection with the research conducted, the following hypothesis was formulated:

$\boldsymbol{H}_{1}$ : $\quad$ Product has a positive and significant effect on purchasing decisions on minimarkets with campus brands.

$\mathrm{H}_{2}$ : $\quad$ Price has a positive and significant effect on purchasing decisions on minimarkets with campus brands.

$\boldsymbol{H}_{3}$ : $\quad$ Promotion has a positive and significant effect on purchasing decisions on minimarkets with campus brands.

$\boldsymbol{H}_{4}$ : $\quad$ Service has a positive and significant effect on purchasing decisions on minimarkets with campus brands.

$H_{5}$ : Place/location has a positive and significant effect on purchasing decisions on minimarkets with campus brands.

\section{Research Method}

This research is a quantitative study, a study with data acquisition in the form of numbers or qualitative data that was framed. Data were obtained from a sample of the study population, which were then analyzed using the multiple linear regression method and interpreted. The population in this study were consumers who had made purchases at a minimarket with a campus brand in the Banyumas Regency. The sampling employed a non-probability method with a purposive sampling technique with specific criteria: consumers who were more than 17 years old. This study used primary data; namely, data sourced from questionnaires addressed to minimarket consumers and research locations (Boersa Kampus, Top Kampus, Kopkun Swalayan, Indo Kampus, and UeMPe Mart) in July - August 2019. The number of questionnaires distributed was 110 copies with a return rate of $95 \%$; the number of questionnaires used was 100 copies.

Before data analysis, validity, reliability, and classic assumptions were tested (normality, multicollinearity, heteroscedasticity, and autocorrelation tests). Data analysis testing utilized multiple linear regression by SPSS 22 program, and the hypothesis testing used the coefficient of determination test $\left(R^{2}\right), F$ statistical test, and t statistical test (Ghozali, 2016).

\section{Validity and Reliability Test}

The validity test results showed that the research instrument was valid because of all values calculated $>r$ table (0.1966), with a significance value of $<0.05$. Thus, it can be concluded that the statement on each variable of product, price, promotion, service, and place/location was declared valid and could be used in research. Meanwhile, the 
Cronbach's Alpha value was $0.817>0.6$, which indicates that the indicators used in the statement on each variable were declared reliable.

\section{Classical Assumption Test}

The normality test using Kolmogorov-Smirnov showed that the Asymp. Sig value (2tailed) was 0.165 . This value met the provisions of the Sig. $>0.05$, meaning that the data were normally distributed.

Multicollinearity test results indicated that each variable's tolerance value did not exist below 0.100 , while the VIF value of each variable was not above 10.00 . Therefore, it can be concluded that there were no symptoms of multicollinearity.

Heteroscedasticity test using the Park Test was found that all variables had a Sig. $>0.05$. Thus, it can be concluded that there were no symptoms of heteroscedasticity.

Autocorrelation test showed the results of dU (1.7790) <Durbin Watson (1.851) <4-dU (2.222), with a significance of $5 \%$. Consequently, it can be concluded that there were no symptoms of autocorrelation.

Thus, classic assumptions had been fulfilled (normality, multicollinearity, heteroscedasticity, and autocorrelation).

\section{Data Analysis Test}

Data analysis test using multiple linear regression analysis was used to determine whether partially, the independent variables significantly influenced the dependent variable. Based on the data analysis test, the coefficient of the product variable $\left(X_{1}\right)$ was 0.184 , the price variable $\left(X_{2}\right)$ was 0.141 , the promotion $\left(X_{3}\right)$ was 0.070 , the service $\left(X_{4}\right)$ was 0.126 , and the place/location $\left(X_{5}\right)$ was 0.410 .

\section{Determination Coefficient Test $\left(\mathbf{R}^{2}\right)$}

Based on the results of the coefficient of determination test, obtained Adjusted Rsquare value is 0.580 , which means that the dependent variable $(Y)$ is influenced by the independent variable $(X)$ of $58 \%$. Meanwhile, the rest is influenced by other variables outside the independent variable under study.

\section{Statistical Test $\mathbf{F}$}

If the Sig. is $<0.05$, it means that the independent variable $(X)$ simultaneously influences the dependent variable $(Y)$. Value $F_{\text {table: }}(k-1)(n-k)=(6-1)(97-6)=(5)(91)$ on $F_{- \text {table }}$ worth of 2.31 .

Statistical $\mathrm{F}$ test results indicated that the value of $\mathrm{F}_{\text {-count }}>\mathrm{F}$-table $(27.507>2.31)$, with the value of Sig. $<0.05(0,000<0.05)$. It can be concluded that the product, price, promotion, 
service, and place/location simultaneously influenced the purchasing decision on a minimarket with a campus brand in the Banyumas Regency.

\section{Statistical Test t}

If the $t_{\text {count }}>t_{\text {table, }}$ it means that the independent variable $(X)$ partially has a positive effect on the dependent variable $(Y)$. In contrast, if the $t_{\text {count }}<-t_{\text {table, }}$ it means the independent variable $(X)$ partially has a negative effect on the dependent variable $(Y)$. Meanwhile, the value of $t_{\text {table }}<t_{\text {count }}<t_{\text {table }}$ means that the independent variable $(X)$ partially has no effect on the dependent variable $(Y)$. Value of $t_{\text {table }}$ was $(\alpha / 2 ; n-k-1)=$ $(0.05 / 2 ; 97-5-1)=(0.025 ; 91)=1.98638$, thus the conclusion of the statistical t-test is as follows:

a. Product $\left(\mathrm{X}_{1}\right)$ : had a $\mathrm{t}$-count of 2.703 , while $\mathrm{t}$-table was 1.986 . The value of $\mathrm{t}$-count $>\mathrm{t}$-table $_{\text {- }}$ $(2.703>1.986)$ with a Sig. $<0.05$, which was 0.008 . Then, it means the product had a positive and significant influence on purchasing decisions so that the Hypothesis ( $\mathrm{Ho})$ was rejected and $(\mathrm{Ha})$ was accepted. Thus, the first hypothesis stating that the product had a positive and significant effect on purchasing decisions on minimarkets with campus brands in the Banyumas Regency was declared acceptable.

b. Price $\left(\mathrm{X}_{2}\right)$ : had a $\mathrm{t}$-count of 1.688 , while $\mathrm{t}$-table was $1.986 . \mathrm{t}$-count $<\mathrm{t}$-table $(1.688<1.986)$, with a Sig. $>0.05$, which was 0.095 . Then, it indicates that the price did not affect the purchase decision so that the Hypothesis $(\mathrm{Ho})$ was accepted and $(\mathrm{Ha})$ was rejected. Thus, the second hypothesis, which stated that prices had a positive and significant effect on purchasing decisions on minimarkets with campus brands in the Banyumas Regency, was declared rejected.

c. Promotion $\left(\mathrm{X}_{3}\right)$ : had a $\mathrm{t}$-count of 1.201 , while $\mathrm{t}$-table was 1.986 so that $\mathrm{t}$-count $<\mathrm{t}$-table $(1.201<1.986)$ with a Sig. $>0.05$, which was 0.233 . Then, it means that promotion had no effect on purchasing decisions so that Hypothesis ( $\mathrm{Ho}$ ) was accepted and ( $\mathrm{Ha}$ ) was rejected. Thus, the third hypothesis, stating that promotion had a positive and significant effect on purchasing decisions on minimarkets with campus brands in the Banyumas Regency, was declared rejected.

d. Services $\left(\mathrm{X}_{4}\right)$ : had a $\mathrm{t}$-count of 1.265 , while a $\mathrm{t}$-table was 1.986 , so that $\mathrm{t}$-count $<\mathrm{t}$-table $(1.265<1.986)$ with a Sig. $>0.05$, which was 0.209 . Then, it indicates the service had no effect on purchasing decisions so that Hypothesis $(\mathrm{Ho})$ was accepted and $(\mathrm{Ha})$ was rejected. Thus, the fourth hypothesis, which stated that service had a positive and significant effect on purchasing decisions on minimarkets with campus brands in the Banyumas Regency, was declared rejected.

e. Place/Location $\left(\mathrm{X}_{5}\right)$ : had a $\mathrm{t}$-count of 5.641 , while a $\mathrm{t}_{\text {-table }}$ of 1.986 so that $\mathrm{t}$-count $>\mathrm{t}$-table $(5.641>1.986)$ with a Sig. $<0.05$, which was 0,000 . Then, it means the place/location had a positive and significant effect on purchasing decisions so that the Hypothesis ( $\mathrm{Ho})$ was rejected and $(\mathrm{Ha})$ was accepted. Thus, the fifth hypothesis, stating that place/location had a positive and significant effect on purchasing decisions on 
minimarkets with campus brands in the Banyumas Regency, was declared acceptable.

\section{Result and Discussion}

Minimarkets with campus brands established in the campus environment in the Banyumas Regency showed a phenomenal and interesting development to be studied. Their existence is a differentiator amid the rapid development of national network minimarkets. They were able to show that they were able to compete and still exist until now. Starting from the establishment of Boersa Kampus in 1999 within the campus of Jenderal Soedirman University (Unsoed), followed by the establishment of Top Kampus (Unsoed and Muhammadiyah University Purwokerto), Kopkun Swalayan (Unsoed), and Indo Kampus (STAIN Purwokerto), followed by the establishment of UeMPe Mart in the UMP campus environment in March 2017, it showed that minimarkets with campus brands increasingly exist in the midst of fierce competition in the retail industry. The existence of a minimarket with a campus brand in the Banyumas Regency illustrates managerial efforts to be able to face the intense competition in the retail world.

For example, Boersa Kampus was with an average of 1,000 people per day (open 24 hours), and its turnover reached $\mathrm{Rp} 35,000,000$. There were many mini markets and competitor shops in the campus environment, so management is demanded to be more creative in implementing marketing strategies. The management assumes that promotion is the most influential marketing mix factor. To that end, to increase purchases, Boersa Kampus organized promotional programs through lucky draws and special discounts for specific products. Boersa Kampus also applied a marketing strategy with delivery orders to improve services and capture more consumers.

Meanwhile, the average Kopkun Swalayan was 850 people with a turnover of Rp. 27,500,000 (open at 06.00-24.00 WIB). Kopkun Swalayan carried out promotional programs in the form of price discounts, banded, or bundling to combine certain products in a sales package and lucky draw. The marketing mix factor considered the most influential was its strategic position that is directly across from the head office and main campus of Jenderal Soedirman University, the completeness of goods (products), and lower prices compared to other stores. Therefore, Kopkun Swalayan always maintained the product's completeness and the availability of goods and prices so that consumers were satisfied because they got the right price. It also applied to online services, and consumers could order goods via mobile phones. Thus, the Kopkun Swalayan are expected to compete healthily with minimarkets and are optimistic that competitors are always trusted by consumers.

UeMPe Mart, which was only established in 2017, had an average turnover of $\mathrm{Rp}$ 4,000,000 per day with a total of 300 customers (open from 6:00 a.m. to 11:00 p.m. WIB). The turnover amount is related to UeMPe Mart as a new minimarket, while several traditional shops around the campus have been established since a dozen years ago, and students, campus, and public environment have become customers. It is 
assumed that product and price were the most influential factors to increase purchases. UeMPe Mart promoted low prices through social media (WA, business Instagram) brochures and banners. The stock of goods was also maintained, not stockless, and added to the type of inventory. Along with that, UeMPe Mart encompassed internal campus customers by providing delivery order services to each faculty. For general consumers, low price promotions for household products were given continuously every week.

\section{Effect of products on purchasing decisions}

Based on the results of the $t_{- \text {test, }}$, it is known that the product had a significance value of 0.008 and a $t$-count of 2.703 , meaning that the product variable partially had a positive and significant effect on purchasing decisions on minimarkets with campus brands in the Banyumas Regency. This study results are in accordance with the study (Noskova \& Romanova, 2015) (Irfan, Widarko, \& Slamet, 2017) (Gandhy \& Hairuddin, 2018).

In this study, respondents rated that the products in a minimarket with a campus brand in the Banyumas Regency according to the needs of students, quality, safe, were the product of choice and many choices/types. The highest average respondents in this study set purchasing decisions with consideration because the minimarket offered a variety of product types.

\section{Effect of price on purchasing decisions}

Based on the results of the $t_{\text {-test, }}$ it is known that the price variable partially had no effect on purchasing decisions on minimarkets with campus brands in the Banyumas Regency. It means that the price did not affect consumers in determining purchasing decisions at a minimarket with a campus brand in the Banyumas Regency. This study results are in accordance with the study (Mirabi, Akbariyeh, \& Tahmasebifard, 2015) (Deisy, Lapian, \& Mandagie, 2018).

In this study, respondents considered that prices at minimarkets with campus brands in Banyumas Regency were higher for several types of goods, and sometimes physically, there was no price tag on the goods display, and there were rarely discounts.

\section{Effect of promotion on purchasing decisions}

Based on the results of the $t_{\text {-test, }}$ it is known that the promotion variable partially did not affect purchasing decisions on minimarkets with campus brands in the Banyumas Regency. It indicates that promotion did not affect consumers in determining purchasing decisions at a minimarket with a campus brand in the Banyumas Regency. This study results are in accordance with the study (Haryanto \& Avita, 2013) (Roring, Oroh, \& Gulla, 2015).

In this study, respondents considered that minimarkets with campus brands in Banyumas Regency were still lacking in terms of promotions and giving discounts, 
promotions offered were less attractive, and it was considered that minimarkets with campus brands were only 'ride' of campus fame.

\section{Effect of service on purchasing decisions}

Based on the results of the t-test, it is known that the service variable partially had no effect on purchasing decisions on minimarkets with campus brands in the Banyumas Regency. It implies that the service did not affect consumers in determining purchasing decisions at a minimarket with a campus brand in the Banyumas Regency. This study results are in accordance with the study (Winerungan, 2013) (Octavia, 2019).

In this study, respondents considered that the service at a minimarket with a campus brand in the Banyumas Regency was still lacking; namely, the shopkeeper did not serve well, lacked understanding of the products sold, was not friendly, lacked responsibility, and paid less attention to the neatness and cleanliness factors.

\section{Effect of place/location on purchasing decisions}

Based on the results of the $t_{\text {-test, }}$ it is known that the place/location had a significance value of 0,000 and a calculated value of 5.458. It means that the place/location became a consideration of consumers in determining purchasing decisions at a minimarket with a campus brand in the Banyumas Regency. This study results are in accordance with the study (Noskova \& Romanova, 2015) (Rondonuwu \& Tamengkel, 2016) (Said \& Prihatini, 2016), which showed that the place/location had a positive and significant effect on purchasing decisions.

In this study, respondents rated that the place/location of a minimarket with a campus brand in the Banyumas Regency was strategic, close to the highway, close to the campus, so that it was easily visible and accessible. The highest average respondents in this study set purchase decisions with consideration because the minimarket occupied a strategic location and was easily accessible.

Products and places/locations partially had a positive and significant influence on purchasing decisions at minimarkets with campus brands in the Banyumas Regency. If there were an increase in the value of product and place/location variables, it would increase purchasing decisions. Places/locations that were close to the campus made it easy for consumers to access the minimarket with the campus brand. This easy access made consumers accustomed to shopping at the convenience store. While for product variables, as long as their availability was always met, consumers would shop again. If the product sought was not guaranteed availability, it might be that consumers would look for the product they needed elsewhere.

Meanwhile, promotions and services partially did not affect purchasing decisions on minimarkets with campus brands in the Banyumas Regency. If there were an increase in the value of variable prices, promotions, and services, it would not necessarily increase purchasing decisions. Consumers in this study decided to buy without regard to price, 
also ignoring the promotions offered and the services provided. Minimarket consumers with campus brands prioritized product accessibility and availability over the three variables.

\section{Conclusion}

\section{Conclusions}

Based on research, the results showed that: (1) The product had a positive and significant influence on purchasing decisions at minimarkets with campus brands in the Banyumas Regency. (2) Price did not affect the purchase decision on a minimarket with a campus brand in the Banyumas Regency. (3) The promotion had no influence on purchasing decisions at minimarkets with campus brands in the Banyumas Regency. (4) Service did not influence purchasing decisions at minimarkets with campus brands in the Banyumas Regency. (5) Place/location had a positive and significant influence on purchasing decisions on minimarkets with campus brands in the Banyumas Regency.

\section{Suggestions}

Suggestions in this study are: (1) For minimarkets with campus brands: periodic evaluations of marketing strategies adopted needs to conduct to win the competition: a) product variables and places/locations are maintained and improved by applying zero stockless, especially for fast-moving products, focusing on cleanliness, beauty, neatness, and convenience of consumer shopping; $b$ ) variable prices, promotions, and services are great opportunities to increase profits. Not necessarily with a low-price strategy, the main focus is on a margin that is affordable by consumers. Promotion is carried out creatively and innovatively, for example, digital promotion through social media, and providing effective services. It can be done by enthusiastically welcoming potential customers, communicative, and skilled in serving. (2) For further research: it can a) refine the question/statement items so that a more valid conclusion can be reached; $b$ ) use a broader research sample that is minimarket management with interviews; c) improve by using a SWOT analysis to test the strengths, opportunities, weaknesses, and threats of a minimarket with a campus brand; d) place the campus brand as a mediating variable.

\section{References}

Alma, B. (2007). Manajemen Pemasaran dan Pemasaran Jasa. Bandung: Alfabeta.

APRINDO (2018). https://www.aprindo.id/ini-alasan-kenapa-pengusaha-retail-perlumasuk-aprindo/. Accessed on 27 August 2018

Deisy, M., Lapian, J., \& Mandagie, Y. (2018). Analisis Citra Merek, Harga Produk, dan Kualitas terhadap Keputusan Pembelian Handphone Samsung pada Seluruh Gerai Seluler di IT Center Manado. Jurnal EMBA: Jurnal Riset Ekonomi, Manajemen, Bisnis dan Akuntansi, 6(4), 2288-2297. https://doi.org/10.35794/emba.v6i4.20997 


\author{
Widyastuti, Pujiharto, Tubastuvi, \& Santoso \\ The Effect of Marketing Mix on Purchase Decisions
}

Gandhy, A., \& Hairuddin, J. A. (2018). Analysis of Promotion and Product Differentiation of Jukajo on Consumer Purchase Decision. Binus Business Review, 9(1), 9. https://doi.org/10.21512/bbr.v9i1.3901

Ghozali, I. (2016). Aplikasi Analisis Multivariate dengan Program IBM SPSS 23 (VII). Semarang: Badan Penerbit Universitas Diponegoro.

Haryanto, \& Avita, R. (2013). Strategi Promosi, Kualitas Produk, Kualitas Layanan terhadap Kepuasan Pelanggan pada Restoran McDonald'S Manado. Jurnal Riset Ekonomi, Manajemen, Bisnis dan Akuntansi, 1(4), 1465-1473. https://doi.org/10.35794/emba.v1i4.2923

Hermawan, A. (2012). Komunikasi Pemasaran. Jakarta: Erlangga.

Irfan, F., Widarko, A., \& Slamet, A. R. (2017). Analisis Pengaruh Harga, Pelayanan, Lokasi, dan Keragaman Produk terhadap Keputusan Pembelian. Jurnal Ilmiah Riset Manajemen, 6(1), 195-207.

Kartajaya, H. (2007). On Marketing Mix (Seri 9 Elemen Marketing) (Cetakan Ke). Bandung: PT Mizan Pustaka.

KBBI (2018). https://kbbi.web.id/pasar. (n.d.). KBBI.pdf. Accessed on 27 August 2018.

Kotler, P. (2007). Manajemen Pemasaran-Analisis, Perencanaan, Implementasi, dan Kontrol. Jakarta: Prenhallindo.

Kotler, P., \& Armstrong, G. (2007). Dasar-dasar Pemasaran. Jakarta: Intermedia.

Kotler, P., \& Keller, K. L. (2009). Manajemen Pemasaran. Jakarta: Erlangga.

Mirabi, V., Akbariyeh, H., \& Tahmasebifard, H. (2015). A Study of Factors Affecting on Customers Purchase Intention. Journal of Multidisciplinary Engineering Science and Technology (JMEST), 2(1), 267-273. Retrieved from https://www.semanticscholar.org/paper/A-Study-of-Factors-Affecting-onCustomers-Purchase-Mirabi/4518676346f0734f26d3915cd612f0e44f889df5

Mokhlis, S. (1999). Consumer Values and The Importance of Store Attributes. International Journal of Retail \& Distribution Management, 27(4), 137-144. https://doi.org/10.1108/09590559910268435

Noskova, E. V., \& Romanova, I. M. (2015). Evaluation of Customer Loyalty to Different Format Retailers. Journal of Internet Banking and Commerce, 20, 1-17.

Octavia, R. (2019). Pengaruh Kualitas Pelayanan dan Kepuasan Nasabah terhadap Loyalitas Nasabah PT. Bank Index Lampung. Jurnal Manajemen Pemasaran, 13(1), 35-39. https://doi.org/10.9744/pemasaran.13.1.35-39

Peraturan Pemerintah (2007). Peraturan Presiden Republik Indonesia Nomor 112 Tahun 2007 tentang Penataan dan Pembinaan Pasar Tradisional, Pusat Perbelanjaan dan Toko Modern.

Richard, M. (2019). 2019, Bisnis Ritel Modern Ditarget Tumbuh 10\%. Retrieved from https://ekonomi.bisnis.com/read/20190107/12/876089/2019-bisnis-ritel-modernditarget-tumbuh-10 Accessed on 16 January 2019.

Rondonuwu, G., \& Tamengkel, L. F. (2016). Pengaruh Lokasi Usaha terhadap Minat Beli Konsumen. Jurnal Administrasi Bisnis, 1-8. https://doi.org/10.35797/jab.4.4.2016.13845.\%25p

Roring, F., Oroh, S., \& Gulla, R. (2015). Analisis Harga, Promosi, dan Kualitas Pelayanan terhadap Kepuasan Konsumen pada Hotel Manado Grace Inn. Jurnal Riset Ekonomi, Manajemen, Bisnis dan Akuntansi, 3(1), 1313-1322.

Said, F. A., \& Prihatini, A. E. (2016). Pengaruh Kualitas Pelayanan, Promosi, dan Harga terhadap (Studi Kasus pada Konsumen Carrefour Srondol ). Jurnal Administrasi Bisnis Departemen Administrasi Bisnis Universitas Diponegoro, (024). Retrieved from https://ejournal3.undip.ac.id/index.php/jiab/article/view/14296

Sumarwan, U. (2004). Perilaku Konsumen (Cetakan Kedua). Bogor: Ghalia Indonesia. 
Syahmardi, J. (2017). Eksis di Bisnis Ritel (Cetakan I). Cimahi: Trim Komunikata.

Utami, C. W. (2010). Manajemen Ritel Modern. Jakarta: Salemba Empat.

Verma, H., \& Madan, P. (2011). Factor Analyzing The Store Attributes to Identify Key Components of Store Images. IJMMR, 2(1), 1-21.

Wikipedia (2018). https://en.wikipedia.org/wiki/Marketing_mix. (n.d.). Wikipedia.pdf. Accessed on 27 August 2018.

Winerungan, O. L. (2013). Sosialisasi Perpajakan, Pelayanan Fiskus dan Sanksi Perpajakan terhadap Kepatuhan WPOP di KPP Manado dan KPP Bitung. Jurnal Riset Ekonomi, Manajemen, Bisnis dan Akuntansi, 1(3), 960-970.

https://doi.org/10.35794/emba.v1i3.2301 